\title{
Predicting the climatic risk of myrtle rust during its first year in New Zealand
}

\author{
Robert M. Beresford ${ }^{1, \star}$, Richard Turner ${ }^{2}$, Andrew Tait ${ }^{2}$, Vijay Paul ${ }^{2}$, Gregor Macara $^{2}$, \\ Zhidong D. Yu ${ }^{3}$, Lorin Lima ${ }^{3}$ and Rebecca Martin ${ }^{3}$ \\ ${ }^{1}$ The New Zealand Institute for Plant \& Food Research Ltd, Private Bag 92-169, Auckland, \\ New Zealand. \\ ${ }^{2}$ National Institute of Water and Atmospheric Research, Ltd, Private Bag 14901, Wellington, \\ New Zealand \\ ${ }^{3}$ Ministry for Primary Industries, PO Box 2526, Wellington 6140, New Zealand \\ ${ }^{*}$ Corresponding author: robert.beresford@plantandfood.co.nz
}

\begin{abstract}
After the first detection of myrtle rust (Austropuccinia psidii) on mainland New Zealand in May 2017, the Ministry for Primary Industries sought information about how weather conditions would affect regional and seasonal risk of disease establishment to help plan the incursion response. Using internationally published information, a pathogenprocess model was developed to predict infection, latent period and sporulation in relation to weather variables (temperature, relative humidity and solar radiation). This Myrtle Rust Process Model (MRPM) was implemented by the National Institute of Water and Atmospheric Research Limited using numerical weather model data to produce weekly maps of potential risk. Predicted risk was greatest in northern North Island and decreased further south, but was still substantial in coastal areas of the north-western South Island during summer and autumn. Risk was low in southern coastal areas of the South Island and the lowest risk occurred in mountainous areas, particularly in the South Island. Retrospective analysis of surveillance data showed that the MRPM accurately predicted geographic risk and it is currently in use for tactical planning of incursion surveillance and organism management.
\end{abstract}

Key words Guava rust, eucalypt rust, disease detection, incursion response, biosecurity, climatology, numerical weather forecasting, Climex model, MaxEnt model, ensemble model, Unified Model

\section{INTRODUCTION}

Myrtle rust (Austropuccinia psidii) was first confirmed on mainland New Zealand in Northland on 3 May 2017 (Guy \& Barry 2017), although it had previously been confirmed on Raoul Island in the Kermadec Group on 4 April 2017 (MPI 2017). At the time of writing (16 May 2018), mainland detections had been made in the North Island, as far south as Wellington, and in the Tasman region of the South Island (Fig. 1A). The number of confirmed positive sites, including re-infected sites, is currently 732 . Dates of first detection in each region and the total number of infected sites to date, including re-infections, are: Northland 3 May 2017 (32); Taranaki 17 May 2017 (291); Waikato 21 May 2017 (81); Bay of Plenty 12 June 2017 (162); Auckland 21 November 2017 (102); Wellington 28 November 2017 (37); Manawatu 19 March 2018 (21); Tasman 4 April 2018 (3); Gisborne 13 April 2018 (2); and Coromandel 20 April 2018 (1). The detection rate has varied over time and decreased during winter, to a minimum during September 2017, after which it increased markedly from late 


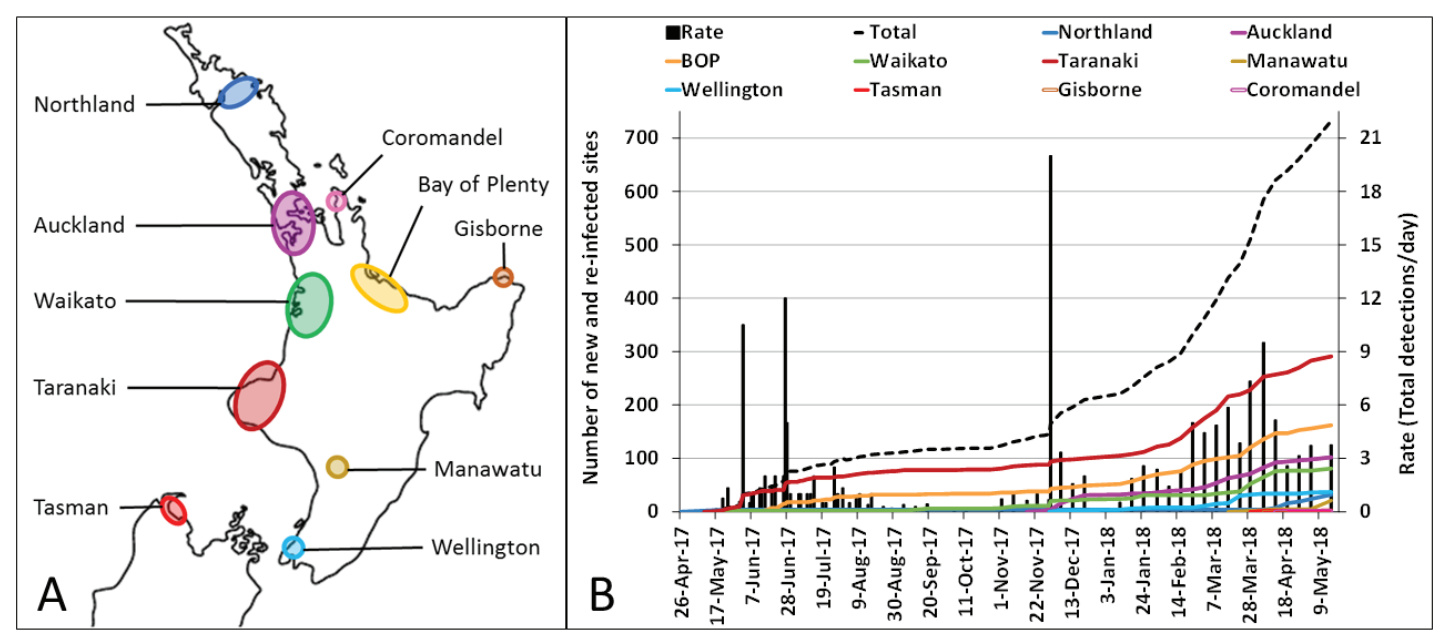

Figure 1 Mainland New Zealand regions where myrtle rust (Austropuccinia psidii) was detected between May 2017 and May 2018 (A), and the daily rate and total number of confirmed positive detections for new and re-infected sites in those regions (B). Data are from publicly available information (Ministry for Primary Industries and Department of Conservation, https://nzppi.co.nz/documents/pests/Myrtle\%20 Rust\%20Stakeholder\%20Update.pdf).

November 2017 and continued with an increasing trend until early April 2018 before starting to decrease again (Fig. 1B). In Northland, after the four positive sites were detected and treated by the Ministry for Primary Industries (MPI) in May 2017, no further detections were made there until April 2018.

The MPI operates a surveillance database and host records show nine Myrtaceae genera for which more than 1,000 plants have been surveyed. Of these, the prevalence of $A$. psidii is currently: 8.64\% on Lophomyrtus spp. (ramarama); 1.76\% on Syzygium spp. (monkey apple); and $1.02 \%$ on Metrosideros spp. (pōhutukawa, northern rata and southern rata). The other six species recorded with infection, which included Leptospermum scoparium (mānuka), each had prevalence $<0.30 \%$. It appears from this information, as well as and from observations in Australia (G. Pegg pers. comm.) that, of the common Myrtaceae species present in New Zealand, ramarama, monkey apple and pōhutukawa/rata are particularly susceptible to $A$. psidii.

Surveillance coordinated by MPI aimed to quantify the spread of $A$. psidii to help interpret risk factors, plan containment and, from April 2018, plan long-term management. To do this effectively, information was required about the suitability of the climate in New Zealand for A. psidii development. Climatic factors are recognised as crucial in determining the rate of spread, geographic range and impact of $A$. psidii (Ruiz et al. 1989, Glen et al. 2007, Booth \& Jovanovic 2012, Alvares et al. 2017). In June 2017, The New Zealand Institute for Plant and Food Research Limited (PFR) and the National Institute for Water and Atmospheric Research Limited (NIWA) began development of a weather-based risk-prediction model to monitor regional and seasonal suitability of weather for A. psidii to assist targeted surveillance efforts by MPI. This paper describes the development and implementation of the Myrtle Rust Process Model (MRPM) in New Zealand and evaluates its performance in relation to previous myrtle rust models and surveillance data collected during the first year since A. psidii arrived in New Zealand. 


\section{METHODS}

\section{Modelling rationale}

The effect of climate on the invasive range of A. psidii has previously been studied using bioclimatic modelling platforms. Those that include specific predictions for New Zealand are: Magarey et al. (2007) using NAPPFAST; Hanna et al. (2012) using MaxEnt; Kriticos et al. (2013) using Climex; and Narouei-Khandan (2014) using ensembles of bioclimatic models. Alvares et al. (2017), on the other hand, used a pathogen process model developed by Ruiz et al. (1989) in Brazil.

Bioclimatic models predict potential areas where a species could spread to, based on the climate in areas where it currently occurs. However, these models may under-estimate geographic range when predicting for new areas (i.e. generate false negative predictions). This can occur if an area used to calibrate the model is climatically suitable for the pathogen, but because of a lack of pathogen records is assumed to be climatically unsuitable. A lack of pathogen records can arise through lack of searching, because something has prevented pathogen arrival (natural barrier) or no susceptible hosts are present. Furthermore, in relation to airborne plant pathogens, current bioclimatic modelling platforms do not represent the requirement for periods of high relative humidity $(\mathrm{RH})$ to allow infection (Magarey et al. 2005). Soil moisture, which is often used instead, may be inappropriate and all these models use time-averaged values of meteorological variables (usually monthly), which do not capture important information about diurnal cycling of infection processes. The relatively coarse time resolution of climate data available in bioclimatic model platforms, and the inability to make near-real time updates, made them unsuitable for the tactical surveillance planning requirement of this study.

Pathogen process models may suffer from representational error if they are developed from controlled environment data that do not relate to field situations. However, providing that the modelled processes are epidemiologically relevant, a process model can be calibrated to give unbiased predictions of climatic suitability by comparing the output with actual field disease data and adjusting the model parameters appropriately. Pathogen-process models can operate at fine time resolution, e.g. hourly, and so they can capture diurnal cycling of temperature and RH. A process model was, therefore, chosen for the MRPM. However, A. psidii could not be studied experimentally in New Zealand to provide data relevant to local conditions because it is currently a controlled organism. Consequently, the model was developed from published international information.

The MRPM predicts daily risk values for three epidemiological processes: (1) infection; (2) latent period; and (3) spore production, which are represented by three respective risk indices. The model does not consider pathogen inoculum, as no near-real time data are available on this, so it identifies potential risk based only on climatic factors. The MRPM also does not use host susceptibility as an input, but rather assumes that the most susceptible myrtaceous hosts, including species of Lophomyrtus, Syzygium and Metrosideros will be those that dictate patterns of spread and severity in New Zealand. As with the bioclimatic models, the MRPM does not currently consider changes in susceptibility of host tissues with age.

\section{Infection sub-model}

The A. psidii infection model developed by Ruiz et al. (1989) used controlled environment data to model infection of urediniospores in relation to wetness duration and temperature. They fitted a double quadratic function, which predicted an infection index (Ii) as follows:

$\mathrm{Ii}=-32.2626+(3.6999 \mathrm{~T})+(0.4613 \mathrm{LWD})-$ $\left(0.0018 \mathrm{~T}^{\star} \mathrm{LWD}\right)-\left(0.0903 \mathrm{~T}^{2}\right)-\left(0.0068 \mathrm{LWD}^{2}\right)$

where $\mathrm{T}=$ temperature during the wet period in ${ }^{\circ} \mathrm{C}$ and LWD = leaf wetness duration in hours (Fig. 2A). However, this model anomalously predicts substantial infection with zero hours of wetness at temperatures around the optimum of $20^{\circ} \mathrm{C}$. This differs markedly from other reports on A. psidii (e.g. Glenn et al. 2007) that indicate a minimum of 6 to 8 hours of moisture 

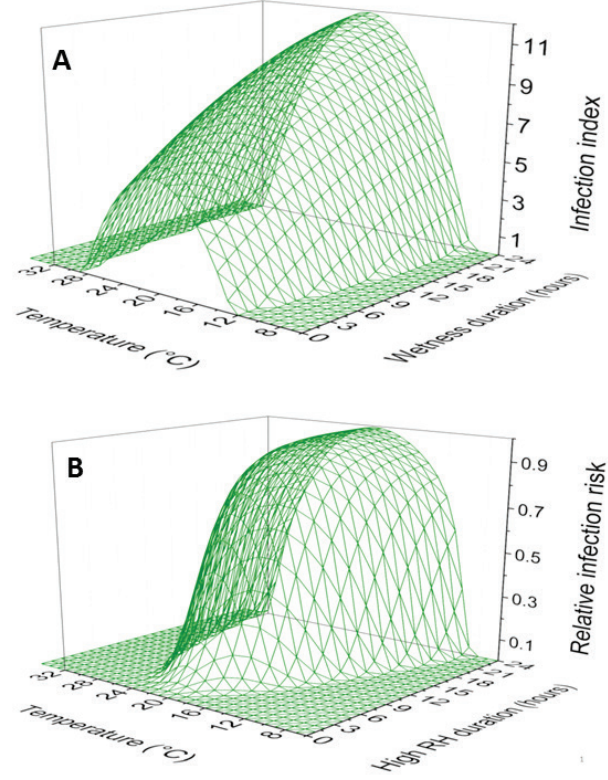

Figure 2 Comparison between the Brazilian model (Ruiz et al. 1989) (A) and the modified model used in the infection sub-model (B), showing predicted infection risk of Austropuccinia psidii in response to duration of moisture (leaf wetness or $\mathrm{RH} \geq 85 \%$ ) and mean temperature during the moist period. are required for infection. The Brazilian model was, therefore, modified to produce a more biologically plausible moisture response by using the Gompertz growth function (Table 1 and Fig. 2B), which had been previously used by Beresford (1986) to model infection of barley leaves by urediniospores of Puccinia hordei. The modified model defined the moisture period as hours of high $\mathrm{RH}(\geq 85 \%)$, rather than hours of surface wetness (Sentelhas et al. 2008), to allow implementation of the model using data sources that lack surface wetness as a parameter, which include standard climate stations and numerical weather models.

Spore germination of $A$. psidii is reported to be favoured by low light intensity (Glen et al. 2007), which may be an adaptation ensuring that spores germinate at night when long wet periods occur. Hourly solar radiation (SR; units $\mathrm{W} / \mathrm{m}^{2}$ ) was used in a linear function, the light inhibition index (L), to predict declining infection risk with increasing light intensity, as follows:

$\mathrm{L}=-0.0008 \mathrm{SR}+1$

The value of $\mathrm{L}$ is 1 at $0 \mathrm{~W} / \mathrm{m}^{2}$ and 0 when solar radiation is $\geq 1250 \mathrm{~W} / \mathrm{m}^{2}$. The infection risk index is calculated daily as the product of $\mathrm{Y}$ (Gompertz function using number of hours with $\geq 85 \% \mathrm{RH}$ and mean temperature during high $\mathrm{RH}$ hours) and the daily mean of the hourly L index values. Calculation of the infection risk index is undertaken daily starting with the hour ending

Table 1 The response of infection risk (Y) to duration of high relative humidity (RH) and temperature (T) used in the infection sub-model. The four-parameter Gompertz function with asymptote (C), point of inflection $(\mathrm{M})$, rate $(\mathrm{B})$ and hours of $\mathrm{RH}>85 \%(\mathrm{X})$, defines the response to moisture and cubic polynomials, with coefficients $\mathrm{P}_{1}$ to $\mathrm{P}_{4}$, define the response of parameters $\mathrm{M}$ and $\mathrm{C}$ to temperature. $\mathrm{Y}$ varies from 0 to 1 .

\begin{tabular}{|c|c|c|c|c|c|}
\hline \multicolumn{6}{|c|}{ Gompertz function, $\mathrm{Y}=\mathrm{C}^{*} \mathrm{EXP}[-\mathrm{EXP}\{-\mathrm{B}(\mathrm{X}-\mathrm{M})\}]$} \\
\hline \multirow{2}{*}{\multicolumn{2}{|c|}{ Gompertz parameter }} & \multicolumn{4}{|c|}{$\begin{array}{l}\text { Cubic polynomial for temperature } \\
{[\mathrm{C} \text { or } \mathrm{M}]=\mathrm{P}_{1} \mathrm{~T}^{3}+\mathrm{P}_{2} \mathrm{~T}^{2}+\mathrm{P}_{3} \mathrm{~T}+\mathrm{P}_{4}}\end{array}$} \\
\hline & & $\mathrm{P}_{1}$ & $\mathrm{P}_{2}$ & $\mathrm{P}_{3}$ & $\mathrm{P}_{4}$ \\
\hline $\mathrm{C}$ & Asymptote & -0.000095 & 0.0012 & 0.0635 & 0.0047 \\
\hline M & Point of inflection & 0.0011 & 0.0917 & -5.3193 & 66.288 \\
\hline $\mathrm{B}$ & Rate & \multicolumn{4}{|c|}{0.39 for all temperatures } \\
\hline
\end{tabular}


Table 2 Weather station locations for five calibration sites used to examine myrtle rust risk indices using 27 months of weather data (January 2016 to April 2018).

\begin{tabular}{llllc}
\hline Land area & Region & \multicolumn{1}{c}{$\begin{array}{c}\text { Weather station } \\
\text { location }\end{array}$} & $\begin{array}{c}\text { Latitude }\left({ }^{\circ} \mathrm{S}\right), \\
\text { longitude }\left({ }^{\circ} \mathrm{E}\right)\end{array}$ & Elevation $(\mathrm{m})$ \\
\hline North Island & Northland & ${ }^{1}$ Kerikeri & $35.18,173.93$ & 20 \\
& Auckland & ${ }^{1}$ Owairaka & $36.89,174.73$ & 40 \\
& Bay of Plenty & ${ }^{1}$ Te Puke & $37.82,176.32$ & 72 \\
& Taranaki & ${ }^{2}$ New Plymouth & $39.01,174.18$ & 30 \\
South Island & Tasman & ${ }^{1}$ Riwaka & $41.10,172.97$ & 15
\end{tabular}

${ }^{1}$ Operated by The New Zealand Institute for Plant and Food Research Limited (PFR) and the National Institute of Water and Atmospheric Research Limited (NIWA)

${ }^{2}$ Operated by the Meteorological Service of New Zealand Limited

at $3 \mathrm{pm}$ New Zealand Standard Time (NZST) when the daily probability of high $\mathrm{RH}$ is lowest. A local implementation of the Brazilian model was used with weather data from five calibration sites (Table 2) to adjust the RH threshold for the MRPM infection sub-model. Values between $75 \%$ and $95 \% \mathrm{RH}$ were tested and a value of $85 \% \mathrm{RH}$ gave the best agreement in seasonal patterns of predicted risk with the Brazilian model (Additional File https://doi.org/10.30843/ nzpp.2018.71.176.91).

\section{Latent period sub-model}

For disease surveillance, knowledge of the time delay between infection and appearance of disease is crucial for interpreting possible infection sources and planning inspections to detect secondary spread. Time from infection to first identifiable symptoms is the incubation period, whereas time to production of uredinia (new inoculum) is the latent period. The latter is important for surveillance because observed symptoms can readily be confirmed as myrtle rust once uredinia have appeared. The latent period for A. psidii is reported to be about 12 days (Ruiz et al. 1989, Glen et al. 2007), although Alfenas et al. (1989) and Pegg et al. (2014) reported uredinia on extremely susceptible hosts 5-7 days after infection. Incubation and latent periods are dependent on temperature, as indicated by Carnegie et al. (2010), where symptom development on susceptible species was delayed during cooler months by 4 to 5 weeks. The response of latent period to temperature has been well characterised for many rusts, but no definitive study has been carried out for A. psidii.

A model for the response of latent period to temperature for $A$. psidii was derived from published latent period information for five other rust species (Fig. 3), using a modification of the function that Hernandez Nopsa and Pfender (2014) used to model the rate of latent development for wheat stem rust (Puccinia graminis f. sp. tritici). The latent period submodel (Table 3 ) assumed that the minimum A. psidii latent period was 12 days, although the parameters can be easily changed if new information suggests that a shorter value would be more appropriate.

\section{Sporulation sub-model}

Disease surveillance and dispersal modelling of pathogen spread both require knowledge of where and when spores are likely to be produced. Temperature is a major determinant of spore production in rust fungi (Teng \& Close 1978) and was used to drive the $A$. psidii sporulation risk model. It was assumed that the temperature response of spore production on host plants in New Zealand would be similar to that for other aspects of the $A$. psidii infection cycle, with an optimum around $20^{\circ} \mathrm{C}$, and substantially 


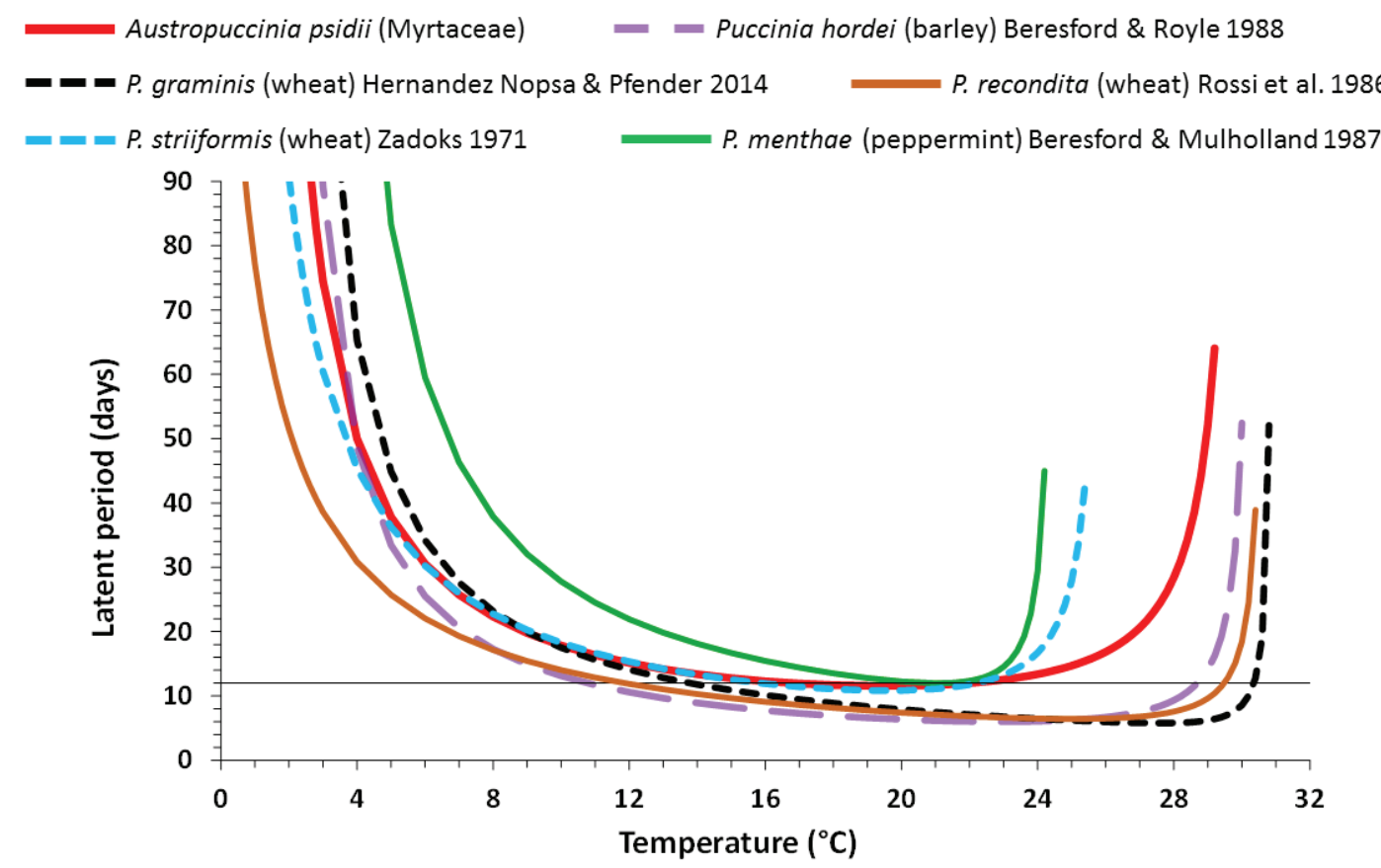

Figure 3 Response of rust latent periods to mean air temperature during the latent period for five Puccinia species on various host, modelled using the equation in Table 3, and the estimated response for Austropuccinia psidii used in the latent period sub-model. The horizontal line at 12 days is the assumed minimum latent period for $A$. psidii.

Table 3 Parameters for the latent period sub-model, which calculates hourly latent development rate $(1 / \mathrm{LP})$ as a function of temperature (T). The step (h) is in hours, $\mathrm{A}$ is the slope of the low-temperature response, Tmin and Tmax are the lowest and highest temperatures for latent development and $\mathrm{R}$ is a rate parameter governing the shape of the curve.

\begin{tabular}{ccccc}
\hline Latent development rate $(1 / \mathrm{LP})$ & $=\mathrm{h} \times \mathrm{A} \mathrm{x}([\mathrm{T}-\mathrm{Tmin}] \mathrm{x}$ & {$\left[1-\mathrm{e}^{\left\{\mathrm{R}^{*}(\mathrm{~T}-\mathrm{Tmax})\right\}}\right]$} & \\
\hline $\mathrm{h}$ & $\mathrm{A}$ & $\operatorname{Tmin}$ & $\mathrm{Tmax}$ & $\mathrm{R}$ \\
1 & 0.0003 & 1 & 30 & 0.1 \\
\hline
\end{tabular}

reduced spore production below $10^{\circ} \mathrm{C}$ and above $25^{\circ} \mathrm{C}$. Spore availability in the field will also be greater when the latent period is shorter, as uredinia will be appearing more rapidly. The sporulation sub-model (Fig. 4) was, therefore, the product of a sporulation index (Table 4), reflecting the hypothesised temperature response and the latent development rate (1/LP) (Table 3). Sporulation risk is calculated hourly and totalled daily.

\section{Myrtle rust model implementation}

The MRPM was used by NIWA to predict spatial patterns of risk using a virtual weather grid produced by the New Zealand Convective Scale Model (NZCSM). Daily values of the risk indices from the infection, sporulation and latent period sub-models were summarised as average daily risk, or latent period, over the previous seven days and presented as colour-coded risk maps. These weekly maps were provided as a weekly 


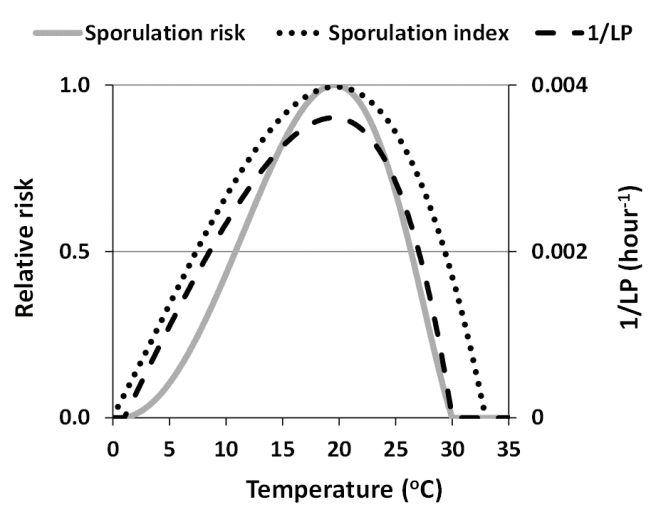

Figure 4 Temperature response for Austropuccinia psidii sporulation risk, which is the product of two functions: the sporulation index and the latent development rate, $1 / \mathrm{LP}$, where LP is the latent period.

operational service to MPI.

The NZCSM is a New Zealand area configuration of the UK Meteorological Office Unified Model (MetUM). It features a non-hydrostatic dynamical core, called New Dynamics (Davies et al. 2005), semi-implicit time-stepping and semi-Lagrangian advection and terrain-following vertical levels. The underlying orography is created at the model resolution of $1.5 \mathrm{~km}$ from the GLOBE source dataset with a horizontal resolution of $1 \mathrm{~km}$ (GLOBE Task Team, 1999). Other important configuration settings for NZCSM are provided in the Appendix. For the period after January 2016 we used short-range $3 \mathrm{pm}$ to $3 \mathrm{pm} \mathrm{NZST}$ NZCSM forecasts of temperature, humidity and solar radiation as inputs into the appropriate MRPM formulae. These were then interpolated (binomial) onto a regular $1-\mathrm{km}$ NZTM grid and averaged over 7 days to get weekly (Sunday through Saturday) values. Because of operational reasons, the initial times of the NZCSM forecasts were 2100 UTC (0900 NZST) prior to and including June 27 2017, and 0000 UTC (1200 NZST) from June 28, 2017.

The gridded NZCSM-based risk predictions were checked for bias against risk predictions from 100 NIWA climate stations around New
Table 4 Parameter values for the Cubic polynomial function used for the sporulation index (S), which describes the relative suitability of temperature $(\mathrm{T})$ for spore production by Austropuccinia psidii.

\begin{tabular}{cccc}
\hline $\mathrm{S}=\mathrm{P}_{1} \mathrm{~T}^{3}+\mathrm{P}_{2} \mathrm{~T}^{2}+\mathrm{P}_{3} \mathrm{~T}+\mathrm{P}_{4}$ & & \\
\hline $\mathrm{P}_{1}$ & $\mathrm{P}_{2}$ & $\mathrm{P}_{3}$ & $\mathrm{P}_{4}$ \\
-0.000095 & 0.0012 & 0.0635 & 0.004655 \\
\hline
\end{tabular}

Zealand for selected weeks in March and August 2017. In calculating the correlations, those station-based records that had missing values for any day of a particular week were removed and station-based latent periods $>300$ days were truncated to 300 days. Time series of the weekly NZCSM-based grid point values nearest to climate stations were also validated over the period May 2015 to September 2017.

\section{Myrtle rust model validation}

Geographic and seasonal patterns of average monthly predicted risk calculated daily at the five calibration sites were examined over 27 months, from January 2016 to April 2018. The last 12 months were after $A$. psidii had been detected on mainland New Zealand. For each site, hourly values of air temperature, $\mathrm{RH}$ and solar radiation were used to run the model. New Zealand surveillance data from MPI and the Department of Conservation (DOC) were used to compare the risk predictions from each MRPM sub-model with $A$. psidii detection data on a regional basis. However, because $A$. psidii has been present in New Zealand for only a short time the currently observed distribution is likely to be influenced by dispersal processes and surveillance intensity, as well as by climate. Additional evaluation of the model's predictions for New Zealand was, therefore, made by comparing the MRPM risk maps with those from other studies that had mapped risk for New Zealand (Magarey et al. 2007; Hanna et al. 2012; Kriticos et al. 2013; Narouei-Khandan 2014). 


\section{RESULTS}

\section{NZCSM weather model validation}

Correlations between NZCSM-based and weather station-based weekly values of the three risk indices for 5 selected weeks over 100 climate stations (Table 5) and for 4 selected stations over 31 months (Table 6) were high. For individual sites and weeks, the biases were generally within
$10 \%$ for sporulation risk and within $15 \%$ for latent period, except for Winchmore, where latent period was biased low by $30 \%$. This was partly caused by a few very long latent periods (>100 days) in the climate station values being represented by latent periods of $\sim 50$ days in the NZCSM-based values. The high relative bias for infection risk at Winchmore is a reflection

Table 5 Average bias and correlation coefficients between NZCSM-based values and climate stationbased values for infection risk, latent period, and sporulation risk for 100 selected climate stations for two high-risk weeks in March 2017 and three low-risk weeks in August 2017.

\begin{tabular}{lcccc}
\hline Week End & Climate Station-Based Avg & NZCSM-Based Avg & Bias & Correl. \\
\hline & \multicolumn{3}{c}{ Infection Risk (0-1) } & \\
11 Mar 2017 & 0.267 & 0.365 & 1.37 & 0.882 \\
25 Mar 2017 & 0.232 & 0.360 & 1.55 & 0.814 \\
05 Aug 2017 & 0.014 & 0.019 & 1.36 & 0.622 \\
12 Aug 2017 & 0.099 & 0.109 & 1.10 & 0.863 \\
19 Aug 2017 & 0.034 & 0.037 & 1.09 & 0.783 \\
& & Latent Period (days) & & \\
11 Mar 2017 & 16.4 & 13.7 & 0.84 & 0.959 \\
25 Mar 2017 & 14.9 & 12.4 & 0.83 & 0.874 \\
05 Aug 2017 & 48.6 & 43.2 & 0.89 & 0.853 \\
12 Aug 2017 & 25.2 & 25.8 & 1.03 & 0.849 \\
19 Aug 2017 & 31.6 & 32.8 & 1.04 & 0.876 \\
& & Sporulation Risk (0-1) & & \\
11 Mar 2017 & 0.735 & 0.741 & 1.01 & 0.962 \\
25 Mar 2017 & 0.721 & 0.738 & 1.02 & 0.949 \\
05 Aug 2017 & 0.247 & 0.239 & 0.97 & 0.861 \\
12 Aug 2017 & 0.473 & 0.443 & 0.94 & 0.946 \\
19 Aug 2017 & 0.405 & 0.380 & 0.94 & 0.827 \\
\hline
\end{tabular}

Table 6 Correlation coefficients between NZCSM-based values of infection risk, latent period, and sporulation risk and climate station-based values at Kerikeri, Te Puke, Riwaka and Winchmore for the period 9 May 2015 to 4 November 2017. Average biases are in square brackets. Note, the period from 9 July to 23 September 2016 was unavailable for comparison.

\begin{tabular}{lccc}
\hline Site & Infection risk & Latent Period & Sporulation \\
\hline Kerikeri & $0.856[0.71]$ & $0.967[0.83]$ & $0.968[1.04]$ \\
Te Puke & $0.903[0.70]$ & $0.957[0.93]$ & $0.975[0.92]$ \\
Riwaka & $0.873[0.97]$ & $0.912[0.84]$ & $0.963[1.08]$ \\
Winchmore & $0.775[1.92]$ & $0.882[0.70]$ & $0.967[1.16]$ \\
\hline
\end{tabular}


of the low average risk rather than a large absolute risk (0.046 compared with 0.024). For the spatial correlations (Table 6), the individual biases ranged from $+10 \%$ to $+55 \%$, but the correlations were excellent, so the relative risks were consistent.

\section{Myrtle rust model implementation}

The MRPM algorithm was completed within 3 months of the first detection of $A$. psidii on mainland New Zealand and the model became operational with provision of weekly risk maps to MPI (Fig. 5) within 4 months (from September 2017). Of the three output risk variables, infection risk showed substantial spatial and temporal variation associated with variability in high RH duration (Fig. 5 and Fig. 6). This index was found to be the most useful for surveillance planning. Latent period risk and sporulation risk, which varied according to regional and seasonal temperatures, were relatively high in most months in coastal areas of the North Island and northern South Island.

\section{Geographic patterns of predicted risk}

Geographic patterns of average infection risk were examined using the mean weekly risk obtained for each point on the NZCSM weather grid from May 2015 to March 2018. The averaged values of infection risk were low (Fig. 7), however, in relative terms, the greatest infection risk occurred in the northern half of the North Island (excluding the Auckland isthmus) and in small areas of north-west Tasman. Intermediate risk occurred on the Auckland isthmus, in North Island areas south of a line between Cape Egmont and East Cape and in coastal parts of the Marlborough Sounds, Tasman and northern West Coast. Lowest risk occurred in the eastern and southern parts of the South Island and at higher elevation. Mapped values of maximum weekly infection risk (Fig. 7), which showed the worst-case infection risk for New Zealand as a whole, showed that high or very high risk could occur in most coastal areas. This depiction may exaggerate risk further south where high or very high risk occurs infrequently.
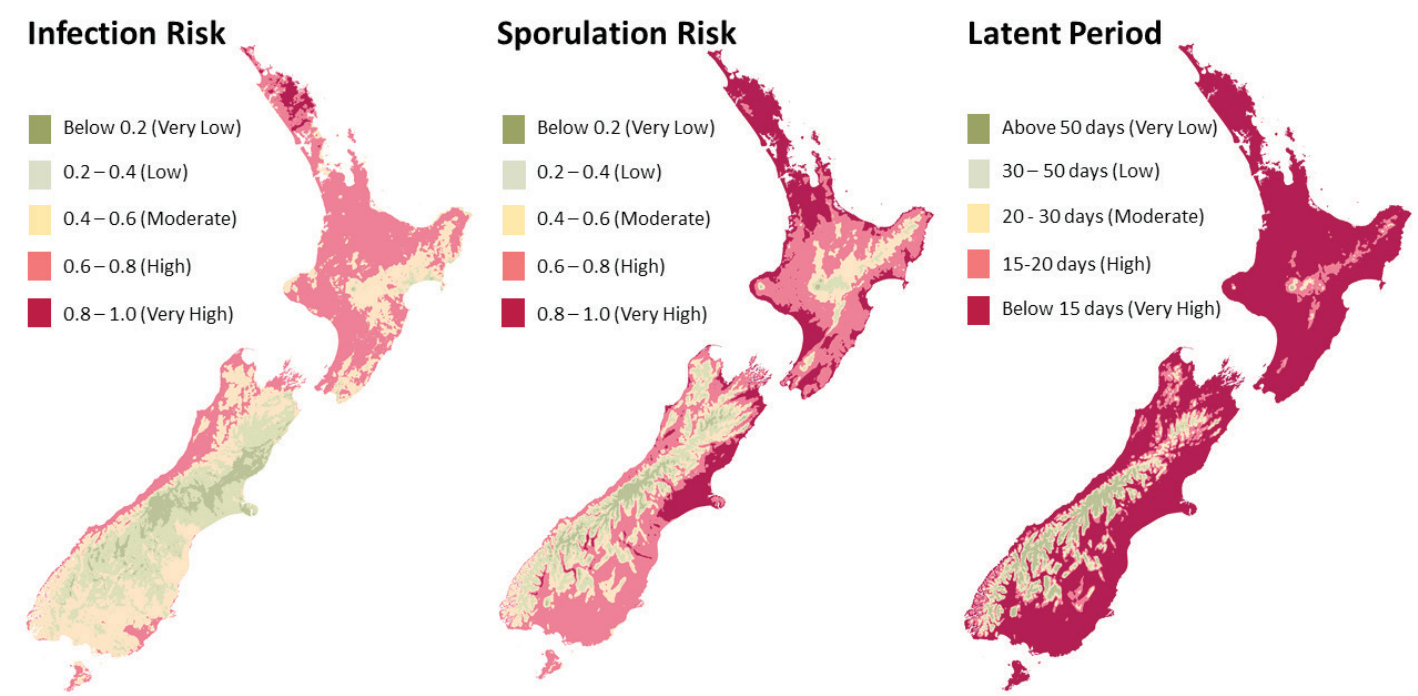

Figure 5 Example of a weekly map generated by the New Zealand Convective Scale Model (NZCSM) for 29 October to 4 November 2017 showing Austropuccinia psidii risk predicted by the infection, sporulation and latent period sub-models. 


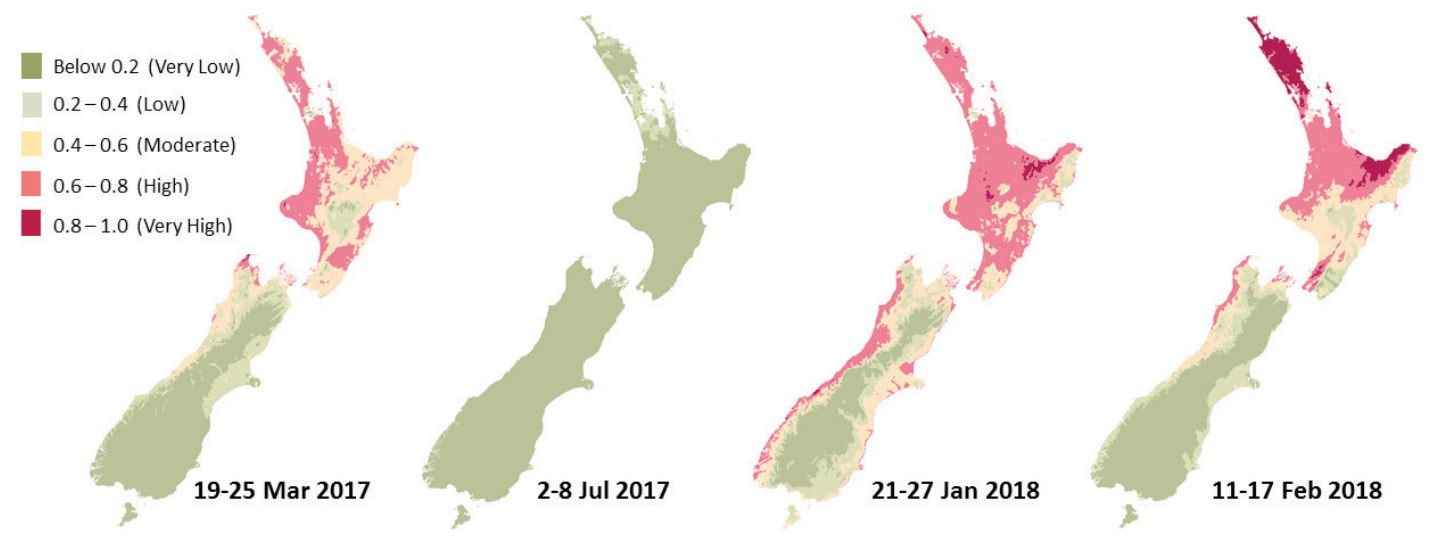

Figure 6 Example weekly Austropuccinia psidii infection risk maps, featuring high risk in the northwest South Island (19 to 25 March 2017), uniformly low risk across all the mainland (2 to 8 July 2017), extensive high risk in the western South Island (21 to 27 January 2018) and very high risk in the upper North Island and eastern Bay of Plenty (11 to 17 February 2018).
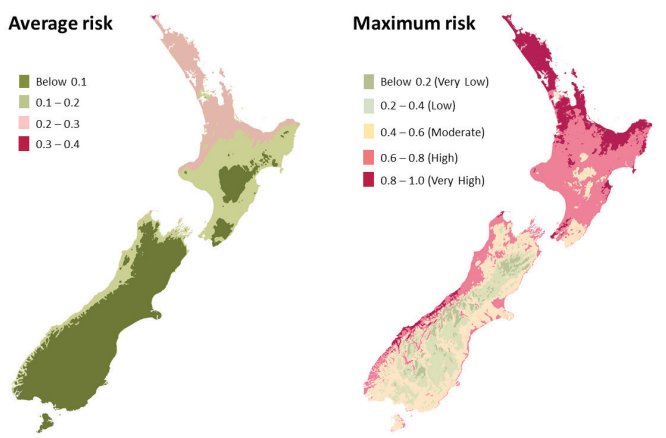

Figure 7 Average and maximum predicted infection risk for Austropuccinia psidii between May 2015 and March 2018, using virtual weather data generated by the New Zealand Convective Scale Model (NZCSM).

\section{Seasonal patterns of predicted risk}

Seasonal trends in predicted latent period and sporulation risk at the five calibration sites (Fig. 8) showed peaks between summer and early autumn (January to March). Shorter latent period (higher risk) occurred at the more northern sites and at all five sites, the shortest latent period in summer was close to the predicted 12-day minimum. For the North Island sites, latent period was almost always less than 20 days (high to very high risk), but at Riwaka in the South Island, in winter, it was greatly extended because temperatures were in the cool part of the temperature response curve (below $10^{\circ} \mathrm{C}$, Fig. 3), where a small decrease in temperature greatly increases latent period. Predicted sporulation risk was high to very high (>0.6) for 9-10 months of each year at all the North Island calibration sites and was $>0.6$ for about 8 months of each year at Riwaka.

For infection risk, which is heavily influenced by high $\mathrm{RH}$ duration, seasonal risk patterns were variable. Highest infection risk consistently occurred further north, although relatively high mean monthly values could occur during summer and early autumn at Riwaka (Fig. 8). In January 2018, mean monthly infection risk was exceptionally high at all five calibration sites, including Riwaka, which was associated with moist northerly air flows and record-high sea temperatures around New Zealand during summer 2017-18. Infection risk tended to peak between early summer and early autumn (December to March). It decreased during autumn and remained relatively low from winter to early spring (April to October), although periods of higher risk could occur during this period. Risk increased again during late spring and early summer. 


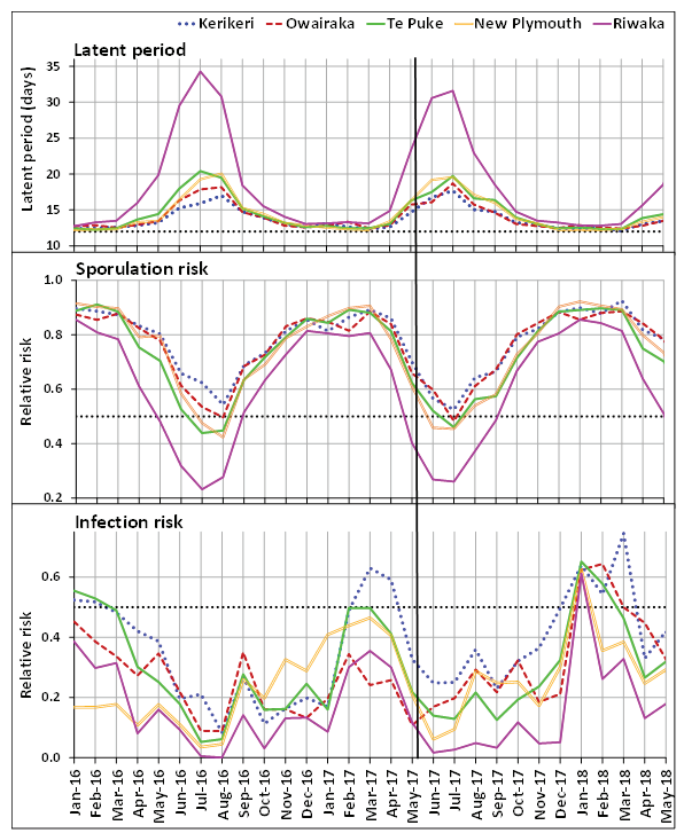

Figure 8 Seasonal trends in monthly averages for Austropuccinia psidii infection risk, latent period and sporulation risk at the five calibration sites from January 2016 to March 2017. Myrtle rust was first detected in New Zealand in early May 2017 (vertical line). Risk categories for infection and sporulation risk are: very low $(0-0.2)$, low (0.2-0.4), moderate (0.4-0.6), high (0.6-0.8) and very high (0.8-1) and for latent period (in days): very low ( $>50)$; low (30-50); moderate (20-30); high (15-20); and very high ( $<15$ days).

\section{Myrtle rust model validation}

Comparing spatial patterns of predicted climatic infection risk with disease detections for a pathogen that is actively spreading, requires caution. True positives (disease predicted and observed) would indicate good accuracy and false negatives (disease not predicted and observed) would indicate poor accuracy. However, true negatives (disease not predicted and not observed) and false positives (disease predicted and not observed) would not be informative because they could arise for nonclimatic reasons, including lack of pathogen or host presence or limited surveillance.
Our interpretation of the spatial and temporal infection risk distribution (Figs. 7 and 8) makes all 10 regions where $A$. psidii was detected between May 2017 and April 2018 (Fig. 1A) true positives. Good accuracy was also indicated for areas predicted to have low climatic suitability by the absence of pathogen detections (no false negatives). Disease was not detected in some areas predicted to have occasional high risk, e.g. Hawke's Bay, Wairarapa and the West Coast, but the pathogen could have been absent from these areas because it had not yet arrived, or there were no hosts, or there was no surveillance. True negatives based on predicted climatic risk cannot be identified from the available surveillance data.

The spatial distribution of risk predicted by the MRPM agreed with the New Zealand Climex map produced by Kriticos et al. (2013) in suggesting that risk is relatively high in North Island lowland areas, but the two disagreed for the South Island. The MRPM predicted moderate risk for Tasman in the north-west South Island and occasional risk for the West Coast and Marlborough regions, but lower risk elsewhere, whereas Kriticos et al. (2013) suggested no South Island risk except for a very small area in the northeast. Results from the MRPM differed substantially from those of Magarey et al. (2007) and Hanna et al. (2012) who predicted low risk for most of the North Island and the South Island. Both the multi-model and the consensus model of Narouei-Khandan (2014), predicted a relatively restricted invasive range, with high risk confined to Northland, Auckland and northern Waikato.

\section{DISCUSSION}

\section{Patterns of predicted risk and actual occurrence of $A$. psidii}

The New Zealand areas predicted by the MRPM to have the greatest climatic risk of myrtle rust establishment are Northland, Auckland (except the isthmus), coastal Bay of Plenty and north Gisborne(EastCape), Waikato, northern Taranaki and north-west Tasman. Predicted risk is slightly lower, but still substantial, for the Auckland isthmus, low elevation areas of Taupo, inland 
Bay of Plenty, southern Taranaki, and the coastal areas of Manawatu-Wanganui, Kapiti CoastWellington, Gisborne, Hawke's Bay, Wairarapa, the rest of Tasman, northern West Coast, Nelson and coastal Marlborough. Eastern South Island areas south of Marlborough have relatively low risk, as does coastal Southland. The lowest risk occurs in mountainous areas, particularly in the South Island. These inferences are based on the spatial trends in average and maximum values of the MRPM infection risk index generated by the NZCSM between 2015 and 2018. The accuracy of these predictions has so far been supported by the detection of A. psidii in Northland, Auckland, Coromandel, Bay of Plenty, north Gisborne, Waikato, Taranaki, Manawatu, Wellington and Tasman. The prediction by the NZCSM of a pocket of particularly high risk in north-west Tasman is concordant with the first South Island detection of $A$. psidii in that area. In Northland, the lack of new detections from May 2017 to April 2018, despite the high predicted infection risk for that region, appears to have been because MPI's early management intervention prevented re-infection for about 11 months. It seems likely with this pathogen that re-infection from outside sources (such as Australia) is always likely to occur, even if localised eradication is possible.

Predicted latent period risk and sporulation risk were generally high throughout New Zealand, except in the far south and at high elevation, indicating that the temperature range over most of the country is quite favourable for these processes. Although the yearly maximum mean temperatures at the more northern sites (about $23^{\circ} \mathrm{C}$ ) slightly exceeded the predicted optimum for $A$. psidii $\left(20^{\circ} \mathrm{C}\right)$, there was only a slight indication in Northland that high summer temperatures reduced the risk index values. However, the possibility of high temperature limitation of myrtle rust risk must be kept in mind in relation to future climate warming.

The ability of the MRPM to produce fine time resolution risk predictions (daily or weekly) has identified that short-term weather variability is important in defining patterns of climatic risk. While this was useful for planning the incursion response, it also indicated that marginal areas, like northwest Tasman, can have occasional days with high risk between summer and early autumn that may promote local establishment of A. psidii in an otherwise unsuitable area. These areas would not be revealed by the mapped output available in current bioclimatic risk models, which typically use monthly averages of climatic variables.

\section{MRPM compared with bioclimatic models}

The MRPM agreed with the Climex model (Kriticos et al. 2013) that the northern North Island is high risk, but predicted a wider invasive range, that included the Tasman and northern West Coast regions in the South Island. The MRPM differed substantially from both the MaxEnt (Hanna et al. 2012) and the NAPPFAST (Magarey et al. 2007) models, both of which predicted low or no risk for most of New Zealand. On a global scale, MaxEnt predicted that high risk was restricted to a relatively narrow band of latitude in the tropics and NAPPFAST predicted large areas of high risk throughout the tropics and subtropics, but with a sharp cut-off at higher southern latitudes that excluded most of New Zealand and much of south-eastern Australia. Pathogen presence data from New Zealand (this article) and from southern New South Wales, Victoria and Tasmania (PBCRC 2018) show that both these models have underestimated establishment risk in these more southern areas.

Stewart et al. (2017) repeated the MaxEnt analyses of Hanna et al. (2012) using data on $A$. psidii presence in different regions. They grouped geographically referenced isolates according to genetic markers (multilocus genotypes) and subjected each group to a separate bioclimatic analysis. The geographic risk predicted for the 'Pandemic' strain (C1/C4 grouping), which is the one identified as present in Australia and New Zealand, was low for all of New Zealand. The highest risk, which was predicted for Northland and Auckland, had a MaxEnt probability of occurrence $\leq 10 \%$ and the risk predicted elsewhere was negligible. This analysis, therefore, failed to predict at least seven out of the $10 \mathrm{New}$ 
Zealand regions in which $A$. psidii has actually established. The approach taken by Stewart et al. (2017) of using separate bioclimatic risk analyses for strains identified by arbitrary genetic markers runs the risk that the chosen markers may not correlate with environmental adaptation of the pathogen. Empirical evidence would be required from controlled environment experiments that strains in the different genetic groupings actually show measurable differences in their response to variables like temperature and $\mathrm{RH}$.

\section{Austropuccinia psidii arrival in New Zealand and sources of infection}

The exact date of arrival of $A$. psidii on mainland New Zealand is unknown, but for Taranaki, where myrtle rust was first detected early in the overall response and where the greatest number of regional detections occurred in the first year, a theoretical date for the first infection can be estimated. Logit linearisation of the disease detection curve (Figure 1B) from 17 May (first detection) to 31 August 2017 (when the seasonal detection rate slowed to its minimum), followed by linear regression and backward extrapolation, suggest that the first infection in Taranaki occurred on 29 March 2017. Myrtle rust was, thus, predicted to have been undetected in Taranaki for 43 days after it may have first arrived. This brief analysis is only approximate because variations in surveillance intensity will have influenced the detection rate; however, it does provide an insight into the sort of delay that can be expected between the arrival and the detection of $A$. psidii in a new region. This has important implications for future control efforts, as it suggests that $A$. psidii was present and sporulating for quite a long time before detection, which would have made successful eradication unlikely. It seems likely that $A$. psidii arrived in New Zealand by wind transport across the Tasman Sea (Kim \& Beresford 2008; R. Turner unpublished data), but it is not known whether its ongoing appearance in new regions has occurred as a result of continued arrival from offshore sources or from spread within New Zealand. The latter is expected to become more important over time. Most of the regions that became infected during the first year of the incursion were exposed to the west, which might suggest arrival from Australia, however, the western regions are also more climatically favourable for myrtle rust than eastern regions, according to the MRPM.

\section{Effect of host growth on disease risk}

The low number of new detections from late June to late October 2017 may have been caused by seasonal low temperatures affecting pathogen processes, but another important consideration is seasonal variation in host growth. Leaf and shoot tissues of susceptible myrtaceous hosts show a change from high susceptibility to resistance (ontogenic resistance) with increasing age (Xavier et al. 2015). When this interacts with seasonal flushes of host growth (Tessman et al. 2001) we believe it causes host-mediated seasonality of infection risk, with increased risk during periods of rapid shoot growth, particularly from spring through autumn. The winter decline in new $A$. psidii detections from the surveillance data is consistent with declining leaf emergence rates in the Lophomyrtus, Syzygium and Metrosideros host species. In fact, the seasonal variation in the A. psidii detection rate in New Zealand appeared more consistent with variation in host growth than with variation in climatic infection risk.

\section{CONCLUSIONS}

The MRPM was developed as a collaborative effort to provide government agencies with important planning information during the initial phase of the myrtle rust incursion response in New Zealand. Use of the MRPM, linked to the NZCSM weather model, provided precise risk information with fine time resolution that was highly suitable for its tactical surveillance purpose.

The MRPM provided more accurate prediction of the New Zealand regions where A. psidii has actually established than the bioclimatic models that have previously predicted climatic risk in New Zealand. Unlike the bioclimatic models, the MRPM has identified areas in more southern latitudes with short seasonal periods suitable for 
A. psidii establishment, including Tasman, where A. psidii has been found, and the West Coast, where it has not yet been found. The risk indicator variables produced by climatic risk models are generally undefined in terms the effects that they predict, e.g. pathogen presence, disease intensity, host damage or an aspect of impact. For the MRPM in New Zealand, ongoing calibration of the risk indices to better define their meaning will occur as more surveillance data comes to hand and as the impact of the disease becomes apparent.

Other factors that should be quantified for their effect on myrtle rust risk and incorporated into the MRPM are host density, host growth and pathogen spore load. The latter two can be estimated from climatic data and are currently being investigated by PFR and NIWA, respectively. With the myrtle rust response moving into long-term management from April 2018, the MRPM will be further used to underpin disease management planning for at-risk species of Myrtaceae in the natural estate, the urban environment and in commercial crops, such as feijoa and mānuka) that may be impacted by $A$. psidii.

\section{ACKNOWLEDGEMENTS}

This work was funded by the Ministry for Primary Industries. We gratefully acknowledge the help of the following people during this study: Warwick Henshall, Gareth Hill and Lucia Ramos Romero of Plant and Food Research, Heather Duarte of the Ministry for Primary Industries, John Powell and Trevor Carey-Smith of NIWA and Quenten Higgan of AsureQuality. We acknowledge MetService, NIWA, and PFR for use of hourly meteorological data from selected observing stations and the PFR Myrtle Rust Response Group for coordinating information about the myrtle rust incursion. We also acknowledge the EcoConnect operations team at NIWA for maintaining the archive of NZCSM outputs.

\section{REFERENCES}

Alfenas AC, Demuner NL, Barbosa MM 1989. A ferrugem e as opções de controle. Correio
Agrícola 1:18-20.

Alvares CA, Sentelhas PC, Mattos EM, Miranda AC, Moraes WB, Silva PHM Furtado EL, Stape JL 2017. Climatic favourability zones for Eucalyptus rust in Brazil. Forest Pathology 47(1) DOI: 10.1111/efp.12301.

Beresford RM 1986. Epidemiological studies on the forecasting of barley brown rust (Puccinia hordei) in England. Ph.D. thesis, University of Bristol, January 1986, $161 \mathrm{p}$.

Beresford RM, Mulholland RI 1987. Mint rust on cultivated peppermint in Canterbury: Disease cycle and control by flaming. New Zealand Journal of Experimental Agriculture 15: 229-233.

Beresford RM, Royle DJ 1988. Relationships between leaf emergence and latent period for leaf rust (Puccinia hordei) on barley spring barley, and their significance for disease monitoring. Zeitschrift fur Pflanzenkrankheiten und Pflanzenschutz 95: 361-371.

Booth TH, Jovanovic T 2012. Assessing vulnerable areas for Puccinia psidii (eucalyptus rust) in Australia. Australasian Plant Pathology 41: 425-429.

Carnegie AJ, Glen M, Mohammed C 2010. Rapid screening of commercial forestry species to Uredo rangelii (myrtle rust) and distinguishing $U$. rangelii from Puccinia psidii (guava rust). Project No: PRC179-0910. August 2010. Report prepared for Forest \& Wood Products Australia. www.fwpa.com. au. 22 p.

Davies, T, Cullen, MJP, Malcolm, A, Mawson, $\mathrm{MH}$, Staniforth, A, White, AA, Wood, N, 2005. A new dynamical core for the Met Office's global and regional modelling of the atmosphere, Quarterly Journal of the Royal Meteorological Society 131:1759-1782. (http://onlinelibrary.wiley.com/doi/10.1256/ qj.04.101/pdf).

Guy N, Barry M 2017. Response underway following myrtle rust find. https://beehive. govt.nz/release/response-underwayfollowing-myrtle-rust-find. 5 May 2017.

Glen M, Alfenas AC, Zauza EAV, Wingfield MJ, 
Mohammed C 2007. Puccinia psidii: a threat to the Australian environment and economy-a review. Australasian Plant Pathology 36(1): $1-16$.

GLOBE Task Team and Hastings, DA, Dunbar, PK, Elphingstone, GM, Bootz, M, Murakami, H, Maruyama, H, Masaharu, H, Holland, P, Payne, J, Bryant, NA, Logan, TL, Muller, J-P, Schreier, G, MacDonald, JS, eds. 1999. The Global Land One-kilometer Base Elevation (GLOBE) Digital Elevation Model, Version 1.0. National Oceanic and Atmospheric Administration, National Geophysical Data Center, Colorado, USA. http://www.ngdc. noaa.gov/mgg/topo/globe.html.

Hanna JW, Neves Graça R, Kim M-S, RossDavis AL, Hauff RD, Uchida JY, Kadooka CY, Rayamajhi MB, Arguedas Gamboa M, Lodge DJ, Medel Ortiz R, Lopez Ramírez A, Cannon PG, Alfenas AC, Klopfenstein NB 2012. A bioclimatic approach to predict global regions with suitable climate for Puccinia psidii. In: Zeglen S, Palacios P, comp. Proceedings of the 59th Annual Western International Forest Disease Work Conference, October 2011, Washington USA. Pp. 131-136.

Hernandez Nopsa J, Pfender WF 2014. A latent period duration model for wheat stem rust. Plant Disease 98: 1358-1363.

Kim KS, Beresford RM 2008. Use of a spectrum model and satellite cloud data in the simulation of wheat stripe rust (Puccinia striiformis) dispersal across the Tasman Sea in 1980. Agricultural and Forest Meteorology 148: 1374-1382.

Kriticos DJ, Morin L, Leriche A, Anderson RC, Caley P 2013. Combining a climatic niche model of an invasive fungus with its host species distributions to identify risks to natural assets: Puccinia psidii sensu lato in Australia. PLoS ONE 8: e64479 https://doi. org/10.1371/journal.pone.0064479.

Magarey RD, Sutton TB, Thayer CL 2005. A simple generic infection model for foliar fungal plant pathogens. Phytopathology 95: 92-100.

MPI 2017. Serious fungal plant disease found on Raoul Island trees. 04 April 2017. https:// www.mpi.govt.nz/news-and-resources/ media-releases/serious-fungal-plant-diseasefound-on-raoul-island-trees/.

Narouei-Khandan HA 2014. Ensemble models to assess the risk of exotic plant pathogens in a changing climate. Ph.D. thesis, Lincoln University, New Zealand. $280 \mathrm{p}$.

Pegg GS, Brawner JT, Lee DJ 2014. Screening Corymbia populations for resistance to Puccinia psidii. Plant Pathology 63: 425-436.

Plant Biosecurity Cooperative Research Centre (PBCRC) 2018. http://www.pbcrc.com. $\mathrm{au} /$ news $/ 2016 / \mathrm{pbcrc} /$ myrtle-rust-threataustralian-landscape-and-plant-industries. Accessed 15 May 2018.

Rossi V, Racca P, Pancaldi D, Alberti I 1996. Appearance of Puccinia recondita f. sp. tritici on winter wheat: a simulation model. EPPO Bulletin 26: 555-566.

Ruiz RAR, Alfenas AC, Ferreira FA, do Vale FXR 1989. Influencia da temperature, do tempo molhamento foliar, fotoperiodo e da intensidade de luz sobre a infeccao de Puccinia psidii em eucalipto. Fitopatologia Brasileira 14: 55-64.

Sentelhas PC, Dalla Marta A, Orlandini S, Santos EA, Gillespie TJ, Gleason ML 2008. Suitability of relative humidity as an estimator of leaf wetness duration. Agricultural and Forest Meteorology 148: 392-400.

Teng PS, Close RC 1978. Effect of temperature and uredium density on urediniospore production, latent period, and infectious period of Puccinia hordei Otth. New Zealand Journal of Agricultural Research 21: 287-296.

Xavier AA, Costa da Silva A, Mauro da Silva Guimarães L, Matsuoka K, Hodges CS, Alfenas AC 2015. Infection process of Puccinia psidii in Eucalyptus grandis leaves of different ages. Tropical Plant Pathology 40: 318-325.

Zadoks JC 1971. Systems analysis and the dynamics of epidemics. Phytopathology 61: 600-610. 


\section{APPENDIX:}

\section{NZCSM key configuration information}

\begin{tabular}{ll}
\hline Configuration Item & Settings \\
\hline Domain size & $1200 \times 1350 \times 70$ \\
Computational grid & Rotated latitude / longitude \\
Model Top & $40 \mathrm{~km}$ \\
Levels below $2 \mathrm{~km}$ & 23 \\
Dynamics time step & $50 \mathrm{~s}$ \\
Radiation time step & $600 \mathrm{~s} / 10 \mathrm{~min}$ \\
Data Assimilation & Pseudo-analysis (merge NZLAM-12 background) \\
IAU Period & 2 hours (T-1 to T+1) \\
Observation types used & Surface, Aircraft, Satellite (via NZLAM-12 background) \\
Forecast period & 42 hours \\
Forecast frequency & 4 times per day at 03, 09, 15 and 21 UTC (Analysis Time) \\
Forecast availability & Analysis Time plus 6 hours 15 minutes \\
Lateral Boundary Conditions (LBC) & Derived from NZLAM-12 run at 12 km horizontal resolution \\
LBC Update frequency & 30 mins \\
Output frequency & Prognostic fields: 30 mins; Accumulations: Hourly, 3, 6, 12, 24 \\
\hline
\end{tabular}

